\title{
The Allocation of Federal Funds to Promote Bureaucratic Objectives: An Empirical Test
}

Article in Contemporary Economic Policy · February 2002

DOI: $10.1093 /$ cep/20.3.209 $\cdot$ Source: RePEc

CITATIONS

6

2 authors, including:

\section{Shirley Svorny}

California State University, Northridge

40 PUBLICATIONS 285 CITATIONS

SEE PROFILE
READS

22 


\title{
THE ALLOCATION OF FEDERAL FUNDS TO PROMOTE BUREAUCRATIC OBJECTIVES: AN EMPIRICAL TEST
}

\author{
SHIRLEY SVORNY and LEAH MARCAL*
}

\begin{abstract}
This article tests whether Job Training Partnership Act Title III discretionary funds are allocated to meet bureaucratic objectives. These funds are targeted to provide a rapid response to mass layoffs or natural disasters and are therefore well suited for detecting political influence because program distributions are awarded contemporaneously and eligibility is difficult to anticipate. After controlling for worker displacements and disaster declarations, discretionary outlays are higher in states with close congressional races, politically active constituents, and powerful congressional representatives. There is additional evidence of politics in the reduction of aggregate outlays during presidential election years. (JEL D73)
\end{abstract}

\section{INTRODUCTION}

Economists and political scientists have modeled the behavior of public agencies and the bureaucrats that manage them. These models predict that the allocation of federal funds across states will reflect bureaucratic objectives rather than directly serve the stated goals of the enabling legislation. Evidence of bureaucratic politics in the distribution of federal funds is mixed and depends on the choice of control variables and grant type. Rich (1989, 1993) and Morgan and LaPlant (1996) have criticized researchers for using data that is ill suited for observing current political influence and for ignoring important demand variables. If allocations are specified by legislation formulae or made over a period of years, it is difficult to detect current political influence.

This study examines the distribution of discretionary funds under Title III of the Job Training Partnership Act (JTPA). These outlays are well suited for detecting current political influence because program

*The authors thank Robert Krol, Mark Zupan, and two anonymous referecs for their comments. Charles Kaljian provided valuable research assistance.

Svorny: Professor, Department of Economics, California State University-Northridge, 18111 Nordhoff Street, Northridge, CA 91330-8374. Phone 1-818-677-4504, Fax 1-818-677-4903, E-mail shirley.svorny@esun.edu Marcal: Assistant Professor, Department of Economics, California State University-Northridge, 18111 Nordhoff Street, Northridge, CA 91330-8374 Phone 1-818-677-4557, Fax 1-818-677-4903, E-mail leah.marcal@csun.edu distributions are discretionary (rather than formulaic) and contemporaneously applied for and awarded. Furthermore, eligibility for Title III discretionary funds is difficult to anticipate. The allocations are targeted to provide a rapid response to mass layoffs or natural disasters. These unexpected events guide funding, so legislators with budgetary oversight are not certain that funds will be directed to their communities. This eliminates the endogeneity of committee representation that has plagued other studies.

Like many federal programs, program specialists (not politicians) make most of the decisions regarding the allocation of JTPA discretionary awards. JTPA specialists are expected to make allocational decisions that build political coalitions for their program. The specialist may allocate awards to please legislators with budgetary oversight and the secretary of labor, for whom they work. JTPA allocations may therefore reflect the secretary of labor's interest in promoting the objectives of the president and his political party. The influence of congressional committees, agency heads, and powerful politicians on the program specialist's allocations suggest testable hypotheses of bureaucratic politics.

\section{ABBREVIATIONS}

GAO: General Accounting Office

JTPA: Job Training Partnership Act

Contemporary Economic Policy 
One innovation of this article is the use of Congressional Quarterly preelection assessments of the closeness of races to identify marginal districts. The authors test the hypothesis that JTPA Title III discretionary funds are disproportionately distributed to states where races are close and marginal dollars can affect election outcomes.

The empirical results support models of bureaucratic politics. After controlling for worker displacements and natural disasters, the authors find that JTPA discretionary funds are targeted toward states with close congressional races, politically active constituents, and powerful congressional representatives. In addition, aggregate outlays fell in presidential election years. Perhaps the Democratic Congress tried to limit the votes the Republican administration could sway with JTPA discretionary dollars. Alternatively, both parties may have agreed to shift spending toward other programs where discretion and visibility are even greater during presidential election years.

The article is organized as follows. Section II details the JTPA Title III legislation and the procedure for allocating discretionary funds. Section III describes the expected behavior of optimizing political bureaucrats. Section IV describes previous research in this area. Section V presents the empirical results, and section VI concludes.

\section{ALLOCATION OF DISCRETIONARY FUNDS UNDER TITLE III JTPA}

The JTPA Title III program provided training and job search assistance to displaced workers for 16 years. This federal program was replaced by the Workforce Investment Act in 1998. Prior to its lapse, the JTPA program served around 200,000 workers a year at an annual cost of $\$ 275$ million. The original 1982 legislation set aside $25 \%$ of the annual funds for discretionary allocation by the secretary of labor. The discretionary portion was reduced to $20 \%$ when Congress enacted the Economic Dislocation and Worker Adjustment Assistance Act in 1988 (General Accounting Office [GAO], 1990).

Between October 1982 and June 1993, the Department of Labor distributed nearly $\$ 830$ million in discretionary funds. Table 1 lists the individual state totals over this period.
The number of states receiving funds in any given year ranged from $25(1983-84)$ to 50 (1988-89) (see Appendix Table A1).

\section{The Allocation Process}

The JTPA legislation required that Title III discretionary funds be used to provide services to "aid individuals who are affected by mass layoffs, natural disasters, or federal government actions (such as the relocation or closure of facilities)." The secretary of labor was directed to allocate discretionary funds to encourage "a rapid response to economic dislocations," targeting resources to areas that need them most (GAO, 1990, p. 5).

Eligible state and local programs submit proposals for discretionary Title III funding to the secretary of labor, whose office designs and oversees the entire approval process. A 1992 notice in the Federal Register (July 9, 1992, p. 30536) announced the availability of Title III discretionary funds for Program Year 1992 (July 1, 1992, to June 30, 1993). It stated that applications would be accepted on an ongoing basis, allowing states and other applicants to respond to unanticipated worker dislocations. To ensure that funds remained available for unanticipated economic dislocations throughout the program year, some funds were withheld from early allocation. Clearly, there is a great deal of discretion in this allocation process.

\section{BUREAUCRATIC BEHAVIOR}

In a 1989 paper, Rich reviews the theoretical literature on distributive politics by describing four prominent lines of researchbureaucratic politics, pork-barrel politics, grantsmanship, and political-business cycles. Briefly, bureaucrats' allocations are influenced by congressional members with budgetary oversight, agency heads, and powerful politicians, among others. Members of Congress prefer pork-barrel projects that offer broad benefits for all of their constituents. Grantsmanship describes the effort and ability of recipient jurisdictions to attract funds. Finally, political-business cycles explain election-year divergences from trends in spending. It is not only plausible but also likely that all of these factors simultaneously affect federal funding decisions. 
TABLE 1

JTPA Discretionary Spending by State (From Fiscal Year 1983 to Program Year 1993 in Real 1987 Dollars)

\begin{tabular}{lrlr}
\hline State & Discretionary Spending $\mathbf{( \$ )}$ & State & Discretionary Spending (\$) \\
\hline Alabama & $10,694,061$ & Montana & $7,037,964$ \\
Alaska & $3,113,264$ & Nebraska & $3,749,337$ \\
Arizona & $10,866,878$ & Nevada & $6,257,844$ \\
Arkansas & $5,937,652$ & New Hampshire & $2,955,378$ \\
California & $85,016,417$ & New Jersey & $12,748,642$ \\
Colorado & $3,080,054$ & New Mexico & $3,694,156$ \\
Connecticut & $15,340,833$ & New York & $42,395,237$ \\
Delaware & 96,246 & North Carolina & $6,006,161$ \\
Florida & $42,802,711$ & North Dakota & $4,478,059$ \\
Georgia & $16,087,202$ & Ohio & $23,918,363$ \\
Hawaii & $7,976,651$ & Oklahoma & $8,080,753$ \\
Idaho & $4,070,233$ & Oregon & $25,803,939$ \\
Illinois & $36,094,424$ & Pennsylvania & $33,962,809$ \\
Indiana & $20,141,358$ & Rhode Island & $4,088,654$ \\
Iowa & $38,824,906$ & South Carolina & $7,241,468$ \\
Kansas & $12,535,440$ & South Dakota & $3,420,448$ \\
Kentucky & $6,894,949$ & Tennessee & $4,725,886$ \\
Louisiana & $16,017,401$ & Texas & $24,136,051$ \\
Maine & $7,253,494$ & Utah & $11,865,223$ \\
Maryland & $6,634,299$ & Vermont & $2,951,676$ \\
Massachusetts & $23,784,011$ & Virginia & $7,065,116$ \\
Michigan & $24,513,721$ & Washington & $27,943,770$ \\
Minnesota & $26,569,828$ & West Virginia & $10,058,330$ \\
Mississippi & $4,852,328$ & Wisconsin & $18,855,476$ \\
Missouri & $22,622,680$ & Wyoming & 281,715 \\
\hline
\end{tabular}

This article tests a model of bureaucratic politics wherein JTPA program specialists allocate funds to maximize political support for their program, subject to legislative constraints. The JTPA specialist maximizes an objective function that includes his or her own preferences, such as the expansion of the program, and the preferences of the politicians who can affect the specialist's budget or career. The specialist's ability to manipulate the allocation of funds across states is constrained by the JTPA enabling legislation. The legislation requires that discretionary JTPA funds be awarded to areas affected by mass layoffs, natural disasters, or the closure of federal facilities.

Program specialists with permanent tenure should distribute JTPA awards to maximize the size of future funding allocations from the legislature because they benefit from bud- get expansion. ${ }^{1}$ The power of the office of the secretary of labor will also increase with greater funding. JTPA specialists will allocate awards to please the legislators who serve on the House and Senate Appropriations Committees because they set agency budgets.

The JTPA program specialist, who processes award applications in the Department of Labor, will also be influenced by the political preferences of the secretary of labor. The secretary may influence the specialist's future career directly or indirectly through middle managers by affecting raises, promotions, and job references.

In turn, the secretary of labor has an incentive to consider the president's interest in federal fund allocations. Efforts to

1. See Niskanen (1971). The role of bureaucrats in federal agencies is discussed in the work of Heclo (1987) and Light (1995). 
shift resources in directions that please the administration may provide the secretary with financial, political, or other benefits. Under these conditions, the bureau-maximizing program specialist should consider the interests of the president and his political party when allocating JTPA awards.

Political pressures may prompt bureaucrats to shift funds to sway elections. Although political-business cycle models focus on changes in aggregate spending prior to elections, the more general idea is that funding can be manipulated to influence political outcomes. This could include channeling resources to districts where there is a thin electoral majority.

The marginal conditions for finding an optimum can be used to predict the behavior of a program specialist who allocates JTPA funds across states. The specialist's objective function is maximized when funds are allocated so the return to a marginal dollar is equalized across all states. If allocations in one state offer greater returns-perhaps the administration benefits if funds sway a close election there or the state has representation on an appropriations committee-the specialist will increase funding to that state at the expense of others. Optimizing models predict that awards will be spread across the states, because of diminishing returns to the political benefits of JTPA awards in any one state.

If a change in circumstances increases the marginal value of a dollar in a particular state, then the optimizing program specialist shifts incremental JTPA funds to that state. This process continues until the marginal value of the last dollar spent in the favored state falls, and the marginal value of the last dollar allocated to less favored states rises. An optimum is restored when the marginal value of a dollar is equalized across states.

It is important to account for grantsmanship when examining bureaucratic politics. Rich (1989) and Stein (1981) emphasize the role of recipient jurisdictions in the federal fund allocation process. A state's experience and familiarity with securing federal funds will influence not only its allocation but also the extent to which it makes use of lobbyists or consultants in the grant-application process.

\section{PREVIOUS EMPIRICAL STUDIES}

Numerous studies have examined the influence of politics and economics in the federal grant process. Measures of need have been included but are not always significant determinants of federal allocations. ${ }^{-}$

In studies of pork-barrel politics, researchers have examined two measures of congressional influence-membership on relevant Senate and House committees and congressional seniority-with mixed results. Measuring membership influence has been hampered by researchers' inability to control for the endogeneity of committee representation. ${ }^{3}$ If legislators seek positions on committees that allocate funds to their communities, committee membership may be related to the distribution of federal funds for reasons unrelated to committee authority and influence.

Political power should rise with tenure as reputations for vote trading are built and congressional representatives move into increasingly influential committee positions. However, previous studies have not found a relationship between congressional seniority and federal fund allocations. ${ }^{4}$

Levitt and Poterba (1999) examine the effect of legislative seniority and committee representation on income growth at the state level. They test whether powerful state representatives can promote economic activity in a state or influence the allocation of federal funds. They find that representation by junior and senior Democrats and membership on a public works committee affects state income growth, but they are unable to show that representation influences the distribution of federal outlays.

Their regression work also includes two variables for close elections-the closeness of the presidential race and the share of House seats won in close races. Both variables are related to state income growth, however, neither appears to affect the distribution of federal outlays. These observations lead Levitt and Poterba (1999) to suggest that state legislators promote economic growth by alter-

2. See, for example, Wright (1974), Fleck (1995), and Svorny (1996).

3. Past work on committee representation includes Plott (1968), Rundquist and Ferejohn (1975), and Arnold (1979)

4. See Greene and Munley (1981) and Kiel and McKenzie (1983). 
ing regulatory laws and trade policies, rather than through directed federal outlays.

Other researchers have examined the influence of election year politics on federal fund allocations. For example, Wright (1974) found that budget appropriations to New Deal spending peaked prior to the elections of 1936 and 1938. Evidence that discretionary funds were used to sway individual elections is in Fleck (1995) and Wright (1974). They found New Deal expenditures were allocated disproportionately toward marginal Democratic states.

Bickers and Stein (1996) and Stein and Bickers (1994) examined the postelection behavior of newly elected politicians. Their findings suggest that winners of close races seek federal funds for their districts in an attempt to deter future challengers.

Reviews of the empirical literature on distributive politics try to explain why consistent evidence of political influence is not found. Rundquist (1980) suggests that it is not always in the interests of politicians to sway outcomes. Individuals in power affect allocational decisions only when they need support. Clearly, logrolling activities will shift resources not to those in power but to those with whom they are trading votes. This obscures the power-allocation relationship.

Rich $(1989,1993)$ offers several explanations for researchers' inability to uncover the expected political effects. First, many studies fail to capture the entire distribution process because they examine grant allocations over short time periods. Second, the use of aggregate expenditures rather than programspecific expenditures hides political forces. Third, numerous studies do not account for state efforts to obtain funds. Finally, studies examine regional or state level allocations when they should investigate specific grantees and their political ties.

Researchers generally examine federal fund allocations imbedded over time through legislative formulae or multiyear awards. In such cases, the politics of federal fund allocations are not reflected in current committee membership or legislative seniority (Morgan and LaPlant, 1996). This may explain why researchers have been unable to confirm the importance of legislative seniority or committee membership in the grant process.

This article extends the literature by examining 12 years of JTPA Title III programspecific discretionary funding. The authors can isolate contemporaneous political and economic influences over the spatial distribution of federal funds because awards are applied for and received in the same year. Furthermore, the awards are directed toward unanticipated events, which reduces concerns about the endogeneity of committee representation. This work is the first to use preelection estimates of the closeness of congressional races to assess the political nature of JTPA funding.

Twelve years of data address Rich's concern about studies that examine short time periods. Also, the 12-year period facilitates the examination of political-business cycles because it covers three presidential elections and six congressional elections. Unfortunately, the authors cannot address concerns about state-level data because JTPA allocations are unavailable at the district level.

\section{DATA AND EMPIRICAL RESULTS}

The political nature of federal fund allocations is tested by examining discretionary JTPA awards for 50 states over a 12-year period. As mentioned, state allocations are analyzed because the congressional district awards are unavailable. The Federal Outlays database used by Bickers and Stein (1996) does not specify the congressional district of discretionary JTPA awards. Furthermore, state records are often limited to very recent district awards. ${ }^{5}$

A fixed effects tobit model is employed to analyze the 600 observations. The tobit model is adopted because many states have zero awards in any given year. Under these conditions least squares estimates are biased toward zero, as they fail to account for the difference between zero observations and continuous observations (Greene, 1993). The tobit model is adapted to a panel framework with a fixed-effects specification. This technique allows for unobserved state-specific characteristics that are assumed to be constant over time (Maddala, 1987). ${ }^{6}$

5. For cxample, the state of California maintains records for the past four years only. This eliminates the ability to examine discretionary JTPA awards because the program ended in 1998.

6. The random-effects tohit model was also explored. It treats the unobserved state specific characteristics as a random variable just like the error term. The fixed effects approach is chosen because it does not 
TABLE 2

Variable Definitions

\begin{tabular}{ll}
\hline Variable & \\
\hline DISC & Real per capita JTPA Title III discretionary state-level allocations \\
CLOSEHS & Percentage of close House races where incumbent belongs to the same party as the president \\
CLOSEHD & $\begin{array}{l}\text { Percentage of close House races where incumbent does not belong to the same party } \\
\text { as the president }\end{array}$ \\
CLOSESS & Number of close Senate races where incumbent belongs to the same party as the president \\
CLOSESD & Number of close Senate races where incumbent does not belong to the same party as the president \\
VOTE & Percentage of eligible voters who voted in the previous presidential election \\
HSENIOR & Percentage of House representatives with more than eight years of tenure \\
SSENIOR & Percentage of Senators with more than 12 years of tenure \\
HAPP & Indicates representation on the House Appropriations Committee \\
SAPP & Indicates representation on the Senate Appropriations Committee \\
HAPPSUB & Indicates representation on the labor subcommittee of the House Appropriations Committee \\
SAPPSUB & Indicates representation on the labor subcommittee of the Senate Appropriations Committee \\
HOUSE & Percentage of House representatives who belong to the same political party as the president \\
SENATE & Percentage of Senators who belong to the same political party as the president \\
GOV & Indicates the state governor belongs to the same political party as the president \\
STEXPPI & State government expenditures divided by state personal income \\
POP & State population (in thousands) \\
PELECYR & Indicates a presidential election year \\
ELECDUM & Indicates a congressional election year \\
UNEMP & Annual state unemployment rate \\
LAYOFFS & Estimated number of displaced workers with 3 or more years of tenure (in thousands) \\
DISASTER & Number of presidential major natural disaster declarations \\
BASECLOSE & Estimated number of civilian job losses from military base closures (in hundreds) \\
\hline
\end{tabular}

The dependent variable in the fixed effects tobit model $\left(D I S C_{i t}\right)$ is real, per capita dollars of discretionary Title III funds allocated to state $i$ in period $t$ by the JTPA program specialist. The explanatory variables include political factors that influence the specialist's preferences, proxies for grantsmanship, controls for political-business cycles, and the economic conditions that constrain the specialist's ability to manipulate funding. ${ }^{7}$ The regression can be written as

$$
\begin{aligned}
& D I S C_{i t}^{*}=\alpha_{i}+\beta^{\prime} x_{i t}+\varepsilon_{i t}, \quad \varepsilon_{i t} \sim N\left(0, \sigma^{2}\right) \\
& D_{S I S C_{i t}}=D I S C_{i t}^{*} \quad \text { if } D I S C_{i t}^{*}>0, \\
& D I S C_{i t}=0 \quad \text { otherwise, }
\end{aligned}
$$

where $i=1,2, \ldots 50$

$$
\text { and } t=1982,1983, \ldots 1993 \text {. }
$$

assume that state-specific effects are uncorrelated with the explanatory variables. Furthermore, the findings are similar across estimation techniques.

7. Sources of all data are described in the appendix.
The regression estimates the conditional mean of $D I S C_{i t}$ given the political and economic climate in an individual state at a particular time $\left(x_{i t}\right)$. The results include an estimate for the variance of the error term for the $i$ th state in year $t(\sigma){ }^{8}$ Table 2 contains the definitions of the variables and Table 3 reports the regression results including the marginal effects of the regressors calculated at their mean values. ${ }^{9}$ The 50 state effects $\left(\alpha_{i}\right)$ are not reported to conserve space.

Two versions of the fixed-effects tobit model are presented in Table 3. The first regression accounts for state representation

8. The disturbance in the tobit model is assumed to be homoskedastic. The authors performed conditional moment tests for heteroskedasticity and the null hypothesis of homoskedastic disturbances could not be rejected at conventional levels of significance.

9. The estimated coefficients of the explanatory variables in a tobit regression are not the marginal effects normally interpreted in a linear model. The marginal effects are calculated as: $\mathrm{d} E(D I S C \mid x) / \partial x=\Phi\left(\beta^{\prime} x / \sigma\right) \beta$; where $\Phi$ is the standard normal cumulative distribution and $\Phi\left(\beta^{\prime} x / \sigma\right)$ is the probability of nonzero observations. 
TABLE 3

Fixed Effects Tobit Analysis of Discretionary JTPA Spending

\begin{tabular}{|c|c|c|c|c|c|c|c|c|c|}
\hline \multirow{2}{*}{$\begin{array}{l}\text { Regression } \\
\text { Variable }\end{array}$} & \multicolumn{5}{|c|}{ (1) } & \multicolumn{4}{|c|}{ (2) } \\
\hline & Coefficient & $\overline{\mathbf{S E}}$ & Mean of $X$ & Slope & SE & Coefficient & SE & Slope & SE \\
\hline CLOSEHS & 0.0020 & 0.0031 & 3.60 & 0.0011 & 0.0017 & 0.0018 & 0.0031 & 0.0010 & 0.0017 \\
\hline CLOSEHD & $0.0118^{* * *}$ & 0.0039 & 2.61 & $0.0066^{* * *}$ & 0.0022 & $0.0117^{* * *}$ & 0.0038 & $0.0065^{* * *}$ & 0.0021 \\
\hline CLOSESS & 0.0201 & 0.1396 & 0.06 & 0.0113 & 0.0780 & 0.0332 & 0.1394 & 0.0186 & 0.0780 \\
\hline CLOSESD & 0.0873 & 0.2009 & 0.03 & 0.0488 & 0.1124 & 0.0830 & 0.1998 & 0.0465 & 0.1118 \\
\hline VOTE & $0.0236^{*}$ & 0.0136 & 54.46 & $0.0132^{*}$ & 0.0076 & $0.0223^{*}$ & 0.0136 & $0.0125^{*}$ & 0.0076 \\
\hline HSENIOR & $0.0048^{* * * x}$ & 0.0019 & 23.69 & $0.0027^{* * *}$ & 0.0011 & $0.0045^{* *}$ & 0.0019 & $0.0025^{* *}$ & 0.0011 \\
\hline SSENIOR & -0.0009 & 0.0016 & 23.67 & -0.0005 & 0.0009 & -0.0009 & 0.0016 & -0.0005 & 0.0009 \\
\hline$H A P P$ & -0.2291 & 0.1603 & 0.61 & -0.1281 & 0.0896 & & & & \\
\hline$S A P P$ & 0.0115 & 0.1186 & 0.54 & 0.0064 & 0.0663 & & & & \\
\hline HAPPSUB & & & 0.23 & & & -0.0442 & 0.1994 & -0.0247 & 0.1116 \\
\hline SAPPSUB & & & 0.29 & & & 0.0987 & 0.1297 & 0.0552 & 0.0726 \\
\hline HOUSE & 0.0007 & 0.0017 & 47.20 & 0.0004 & 0.0009 & 0.0008 & 0.0017 & 0.0005 & 0.0009 \\
\hline SENATE & -0.0001 & 0.0011 & 50.08 & -0.0001 & 0.0006 & -0.0001 & 0.0011 & -0.0001 & 0.0006 \\
\hline$G O V$ & 0.0559 & 0.0754 & 0.43 & 0.0313 & 0.0421 & 0.0543 & 0.0763 & 0.0304 & 0.0427 \\
\hline STEXPPI & $0.1057^{* * *}$ & 0.0415 & 12.37 & $0.0591^{* * *}$ & 0.0232 & $0.1095^{* * *}$ & 0.0414 & $0.0613^{* * *}$ & 0.0232 \\
\hline$P O P$ & 0.0000 & 0.0002 & 4872.24 & 0.0000 & 0.0001 & 0.0000 & 0.0002 & 0.0000 & 0.0001 \\
\hline$P E L E C Y R$ & $-0.2415^{* * x}$ & 0.0951 & 0.25 & $-0.1350^{* * *}$ & 0.0532 & $-0.2433^{* * *}$ & 0.0950 & $-0.1361^{* * *}$ & 0.0532 \\
\hline ELECDUM & -0.1835 & 0.1465 & 0.50 & -0.1026 & 0.0819 & -0.1699 & 0.1463 & -0.0951 & 0.0819 \\
\hline UNEMP & -0.0326 & 0.0248 & 6.63 & -0.0182 & 0.0139 & -0.0298 & 0.0248 & -0.0166 & 0.0139 \\
\hline LAYOFFS & 0.0031 & 0.0061 & 21.93 & 0.0017 & 0.0034 & 0.0027 & 0.0061 & 0.0015 & 0.0034 \\
\hline DISASTER & $0.1069^{* *}$ & 0.0439 & 0.54 & $0.0598^{* *}$ & 0.0246 & $0.1075^{* * *}$ & 0.0438 & $0.0601^{* * *}$ & 0.0246 \\
\hline BASECLOSE & -0.0013 & 0.0188 & 0.26 & -0.0007 & 0.0105 & -0.0002 & 0.0189 & -0.0001 & 0.0106 \\
\hline$\sigma$ & $0.7156^{* * * x}$ & & 0.0265 & & & $0.7156^{* * *}$ & 0.0266 & & \\
\hline Sample size & 600 & & & & & 600 & & & \\
\hline Log likelihood & -566.78 & & & & & -567.49 & & & \\
\hline
\end{tabular}

Notes: Partial derivatives are computed at the means of the explanatory variables. Conditional mean at sample point (predicted DISC) is 0.342 and the scale factor (probability of nonzero observations) is 0.559 .

${ }^{* * *},{ }^{* *}$, and ${ }^{*}$ indicate basic significance in a two-tailed test at the 1,5 , and $10 \%$ significance levels respectively.

on congressional appropriations committees. The second regression controls for state representation on each appropriation committee's labor subcommittee. To simplify the following discussion of the results, attention is given to the first regression because the coefficients of the shared variables are nearly identical.

\section{A. Close Elections}

An innovation of this study is the use of Congressional Quarterly assessments of the closeness of elections (published prior to November elections) to identify marginal districts. Congressional Quarterly ranks upcoming state elections in one of seven categories: "no clear favorite," "leans Republican," "leans Democrat," "Republican favored,"
"Democrat favored," "safe Republican," and "safe Democrat." The first three categories are used to identify races that are expected to be close. Compared to postelection vote shares, these assessments are more likely to capture the preelection environment under which grants are made.

The marginal political product of federal dollars should be higher in states with close elections. Moreover, Bickers and Stein (1996) and Stein and Bickers (1994) found evidence that politicians involved in close elections are the most aggressive in seeking federal funding for their districts. All else constant, JTPA discretionary allocations should be larger in states where races are close and marginal dollars have the potential to affect election outcomes. 
JTPA Title III discretionary funds are distributed over a program year rather than a calendar year. Spending in the program year prior to an election is used as the relevant funding year for House and Senate races. For example, the discretionary allocations between July 1, 1991, and June 30, 1992 (i.e., program year 1991) are regressed on Congressional Quarterly assessments of races published in October 1992. For program years that do not precede an election, the close race measure is zero. Appendix Table A1 shows the time sequence for all variables used in the analysis.

Four variables are used to describe close races in which an incumbent is running for reelection. CLOSEHS is the percentage of races that are close in the House of Representatives wherein the incumbent belongs to the same party as the president. CLOSESS is similar, but measures the number of close Senate races. CLOSEHD and CLOSESD indicate close elections in the House and Senate, respectively, wherein the incumbent does not belong to the political party of the president.

The administration was under Republican control in almost all of the election years analyzed. Pressure from the administration should therefore lead to greater funding for Republican incumbents in close races. At the same time, however, the House was controlled by a Democratic majority, while the Senate was sometimes Democrat and sometimes Republican controlled. Pressure from Congress might therefore lead to greater funding for Democratic incumbents. Furthermore, incumbents in close races may differ in their efforts to obtain JTPA funds. Based on their philosophies of government, Democrats might see more political benefits in securing grants for job training than would Republicans.

The regression results suggest that funds were secured by Democratic House incumbents. CLOSEHD is statistically significant at the $1 \%$ level in a two-tailed test. A $1 \%$ increase in close House races, wherein the incumbent is not of the same party as the president, increases per capita JTPA awards by 0.66 cents. $^{10}$

10. The estimated conditional mean of DISC for the overall sample is 34.2 cents. The actual sample mean is 31.6 cents.

\section{B. Aiming Funds at the Politically Active}

Discretionary allocations may be useful to politicians interested in generating political support or gathering campaign contributions in recipient states. This strategy should have the biggest return in states with politically active residents. To capture the level of political activity in a state, the authors use the percent of eligible voters who voted in the prior presidential election (VOTE). The use of this measure is consistent with evidence that individuals who make political contributions vote disproportionately (Sorauf, 1992). If the goals of politicians who influence federal funding are served by allocating funds to states with politically active residents, then the coefficient of this variable should be positive.

The regression results suggest that JTPA discretionary allocations are targeted to states where voters are relatively active. Every $1 \%$ gain in voting participation rates is associated with an additional 1.32 cents in per capita JTPA funding. This result is statistically significant at the $5 \%$ level in a onetailed test.

\section{The Influence of Representative Seniority}

Optimizing bureaucrats are likely to favor senior members of Congress for two reasons. First, senior legislators have the best options for vote trading if they have established reputations for adhering to vote-trading agreements. Second, during the period studied, seniority was associated with higher committee rank and influence. JTPA program specialists could reward senior congressional members for their support of bureaucratic and administrative objectives.

HSENIOR is the percentage of districts in a state where members of the House of Representatives have more than eight years of seniority. " Similarly, SSENIOR is the percentage of state senators with more than 12 years of seniority. The coefficients of the seniority variables are expected to be positive.

11. This measure of seniority is preferred over other measures, such as average seniority in years (which can hide senior members) or total seniority in years (which increases with state size). 
The regression results indicate that states with senior members in the House of Representatives receive greater JTPA funding. A $1 \%$ increase in the number of senior representatives raises per capita JTPA awards by 0.27 cents. Isolating current political influence on spending, as done in this study, may be crucial in finding a significant relationship between legislative seniority and state level allocations.

\section{Committee Representation}

States with representation on congressional budget appropriations committees should receive higher JTPA allocations, because congressional budget committee members are expected to increase the budgets of agencies that favor their states.

Regression (1) of Table 3 includes two dummy variables- $H A P P$ and $S A P P$ - to account for state representation on the House of Representatives and Senate appropriations committees. In contrast, regression (2) includes two dummy variablesHAPPSUB and SAPPSUB - to control for state representation on the House and Senate appropriation committees' labor subcommittees. These dummy variables are equal to one if state $i$ has at least one representative on the committee in year $t$ and equal to zero otherwise. The coefficients of these variables are expected to be positive.

The authors do not find that states with representatives on congressional appropriations committees receive higher per capita JTPA discretionary awards. In fact, the signs of the coefficients on the House appropriations committees are negative; however, these results are not statistically significant. It is possible that previous positive findings of committee influence were driven by the endogeneity of committee representation. This work reduces the possibility of endogeneity because JTPA awards are difficult to anticipate.

\section{E. Party Affiliation}

The regression includes three variables to investigate whether the program specialist favors states represented by politicians with the same party affiliation as the president. HOUSE is the share of state House delegates that belong to the same party as the president. SENATE is a similar measure for the Senate. $G O V$ is a dummy variable that equals one if the state's governor has the same political affiliation as the president.

None of the political party variables are statistically significant. Republican congressional representation during a Republican administration and Democratic representation during a Democratic administration appears to have no effect on state JTPA allocations. Similarly, having a governor in the same party as the administration does not benefit states in their JTPA allocation. This result supports the premise that partisan awards are used with discretion and when needed, as in close elections. Awards are not uniformly distributed to all members of a particular party.

\section{F. Grantsmanship}

States that devote more resources to the application process should receive more discretionary JTPA funds. State government expenditures as a percentage of state personal income (STEXPPI) is used to measure the size of the public sector and should capture the potential influence of a state over its JTPA allocation. ${ }^{12}$ States with large public sectors are able to expend more resources on the grant application process. Moreover, states with relatively large public sectors may influence the votes of legislators in other states, improving their fund-raising efforts.

State size is also included in the regressions. Smaller states are expected to attract federal funds more easily. Representation in the Senate favors smaller states. Each state has two senators, which increases the per capita influence of smaller states. The population of each state $(P O P)$ is included to account for differences in state size.

The regression results confirm that states with relatively large public sectors are able to

12. The actual number of grants applied for is too endogenous to be useful. States aware of the political benefits of federal funds should apply disproportionately. 
attract more JTPA funding. A $1 \%$ increase in STEXPPI is associated with an additional 5.91 cents of per capita JTPA funds. This result is statistically significant at the $1 \%$ level in a one-tailed test. However, population size has no effect on state JTPA awards. The coefficient of $P O P$ is quantitatively small and statistically insignificant.

\section{G. Political-Business Cycles}

Two additional variables are included to measure the effects of election year politics on annual JTPA allocations. The program's budget may be altered during election years if Congress or the administration view JTPA discretionary funds as a source of political power. Depending on the relative power of Congress and the administration in budget negotiations and their perceptions of who has more influence over the decisions of the JTPA program specialist, the funds may be increased or decreased to meet political objectives. Two dummy variables are included in the regressions to control for this behavior-PELECYR indicates presidential election years and ELECDUM indicates congressional election years.

The results show a substantial reduction in the amount of Title III discretionary funds in presidential election years, suggesting some political maneuvering in election-year budgets. Per capita JTPA awards are 13.50 cents lower during these years. There is little evidence that funding declined during congressional elections. Although the coefficient of ELECDUM is quantitatively large and negative, it is not statistically significant.

In almost all of the election years analyzed, the Congress had a Democratic majority, but the administration was under Republican control. The results are consistent with attempts by Congress to reduce funding to an administration-controlled discretionary fund. However, the fact that presidents must sign budgetary legislation gives the administration power as well. Reductions in JTPA discretionary allocations during presidential election years may reflect agreement on the part of both the administration and Congress to shift spending away from JTPA to other programs where discretion and visibility is even greater.

\section{H. Economic Conditions}

The specialist's ability to maximize political support for the program by manipulating JTPA awards is constrained by the economic conditions that guide eligibility. JTPA discretionary awards should be targeted to areas suffering from high unemployment, mass layoffs, natural disasters, and military base closings. The legislation intends for these factors to be the only relevant considerations in the allocation of funds. The regressions include four variables to control for needsbased factors in the grant allocation process. UNEMP is the state's annual unemployment rate. LAYOFFS is the estimated number of displaced workers who had three or more years of tenure on their prelayoff job. DIS$A S T E R$ is the number of presidential disaster declarations, and BASECLOSE are the estimated civilian job losses from military base closings.

Given the legislative intent, it is surprising that DISASTER is the only needs-based variable found to have a positive and statistically significant impact on discretionary JTPA awards. The findings indicate that each additional presidential disaster declaration raises per capita JTPA funding by 5.98 cents. Increased worker displacements are also found to raise JTPA funding, although this result is not statistically significant. States with high unemployment rates and military base closings do not receive more JTPA funding. The coefficients of UNEMP and $B A S E C L O S E$ are negative and statistically insignificant. ${ }^{13}$

\section{CONCLUSION}

This article examines the allocation of federal JTPA Title III discretionary funds across 50 states over a 12-year time period. It contributes to an existing literature that measures the degree of bureaucratic politics in the federal grant process.

The use of JTPA discretionary data resolves several problems characteristic of previous work. First, the funds are program

13. These results are not driven by the state-specific effects. State economic conditions fluctuate over time and should not be captured by state-specific effects that are assumed to be constant. Furthermore, the findings are similar across estimation techniques. 
specific, not an aggregate measure of spending that includes different programs. Second, the application for and distribution of funds is contemporaneous to the political and economic measures that are included in the analysis. Third, awards are targeted toward unanticipated events, which reduces the endogeneity of committee representation. Fourth, the 12-year period allows an examination of political-business cycles in federal funding. This study is the first to use preelection estimates of the closeness of congressional races to identify regions where the allocation of federal funds might be the most politically effective.

The results are consistent with models that portray program specialists as rational decision makers who allocate federal funds to promote bureaucratic objectives. After controlling for economic conditions, the authors find that states with close House races and politically active constituents are favored in the allocation process. States with large public sectors and senior House representatives also receive more discretionary funding. Furthermore, the authors find evidence of political-business cycles in program spending. JTPA funding was reduced in presidential election years.

Two findings in particular shed light on previous empirical work. First, researchers have not identified congressional seniority as a significant factor in federal fund allocations. This may reflect their examination of spending patterns that are dictated by previous legislatures, through formulas or multiyear allocations. However, this examination of JTPA discretionary allocations, which are applied for and distributed in one program year, indicates that seniority does matter.

Second, previous findings of congressional committee representation affecting the distribution of federal funds may reflect the endogeneity of committee representation. Congressional committee assignments may be biased by the selection process. For example, legislators from urban areas may seek representation on committees allocating urban renewal funds. Using JTPA data, where endogeneity of committee representation is less problematic, the authors find no significant relationship between funding distribution and states' representation on relevant House and Senate appropriations committees.
Of all the needs-based measures, only presidential disaster declarations were found to increase JTPA Title III discretionary awards. Controls for large-scale worker displacements and military base closings, ostensibly targeted by the program legislation, were statistically insignificant. Despite the legislative constraints set on the program specialist, there is strong evidence of politics in the allocation of JTPA discretionary awards.

\section{APPENDIX: DATA}

\section{A. JTPA Discretionary Spending}

Data provided by Greg Knorr, Employment and Training Administration, Department of Labor, (12/94). Deflated using implicit price deflators for gross domestic product. Table B-3, Economic Report of the President, Fcbruary 1994

\section{B. Legislative Committee Representation and Seniority}

98th Congress 10 the 101st Congress. Politics in America, Congressional Quarterly Inc., Washington DC, c. 1985, 1987, 1989.

102nd Congress and 103rd Congress. The Almanac of American Politics, National Journal, Washington, DC, c. 1991, 1993.

\section{Close Races}

Congressional Quarterly, supplements, October, various years.

\section{Unemployment Rate and Number of} Displaced Workers

Data provided by Steve Hipple, Office of Current Employment Analysis, Bureau of Labor Statistics, Department of Labor (7/99).

\section{E. Estimated Civilian Job Loss from Military Base Closings}

Data provided by Katie Smith, Office of Economic Adjustment, Department of Defense (7/99).

\section{F. Presidential Declarations of Major Disasters}

Data provided by Carl Suchocki, Office of Public Affairs, Federal Emergency Management Agency (7/99).

\section{G. All Other Data}

Statistical Abstract of the U.S., various issucs. 
TABLE A1

JTPA Program Year, Congress, and Elections

\begin{tabular}{|c|c|c|c|c|c|}
\hline Program Year & Dates & $\begin{array}{c}\text { States } \\
\text { Receiving } \\
\text { Funds }\end{array}$ & Congress & $\begin{array}{c}\text { Congressional } \\
\text { Election }\end{array}$ & $\begin{array}{l}\text { Presidential } \\
\text { Election }\end{array}$ \\
\hline Fiscal year 1983 & Oct. $82-$ Sept. $83^{\prime \prime}$ & 33 & 98 th (1983) & - & - \\
\hline $\begin{array}{l}\text { Program year } \\
\text { transition period }\end{array}$ & Oct. 83-June 84 & 25 & 98th (1984) & 84 & 84 \\
\hline Program year 1984 & July 84-June 85 & 34 & 99th (1985) & - & - \\
\hline Program year 1985 & July $85-J u n e ~ 86$ & 38 & 99 th $(1986)$ & 86 & - \\
\hline Program year 1986 & July $86-$ June 87 & 27 & 100th (1987) & - & - \\
\hline Program year 1987 & July $87-J u n e ~ 88$ & 37 & 100th (1988) & 88 & 88 \\
\hline Program year 1988 & July 88 -June 89 & 50 & 101st (1989) & $\cdots$ & - \\
\hline Program year 1989 & July 89 -June 90 & 31 & 101 st $(1990)$ & 90 & - \\
\hline Program year 1990 & July 90-Junc 91 & 28 & 102 nd (1991) & - & - \\
\hline Program year 1991 & July 91-June 92 & 31 & 102 nd (1992) & 92 & 92 \\
\hline Program year 1992 & July 92-June 93 & 34 & 103rd (1993) & - & - \\
\hline Program year 1993 & July 93-June 94 & 31 & $103 \mathrm{rd}(1994)$ & $94^{\circ}$ & - \\
\hline
\end{tabular}

Number of states that received discretionary JTPA funds.

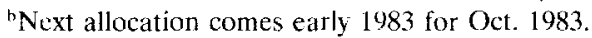

Administrative party is Democrat (Republican for all other years).

\section{REFERENCES}

Arnold, R. D. Congress and the Bureaucracy, A Theory of Influence. New Haven, CT: Yale University Press, 1979.

Bickers, K. N., and R. M. Stein. "The Electoral Dynamics of the Federal Pork Barrel." American Journal of Political Science, 40(4), 1996, 1300-26.

Fleck, R. K. "Electoral Incentives, Benefit Distribution, and the New Deal Realignment." Unpublished manuscript, Montana State University, 1995.

General Accounting Office. Dislocated Workers: Expenditures under Title III of the Job Training Partnership Act. GAO/HRD-90-93FS, Washington, DC: GAO, 1990.

Greene, K. V., and V. G. Munley. "The Productivity of Legislators' Tenure: A Case Lacking in Evidence." Journal of Legal Studies. 10(1), 1981, 207-14.

Greene, W. H. Econometric Analysis. New York: Macmillan, 1993

Heclo. H. "The In-and-Outer System: A Critical Assessment," in The In-and-Outers, edited by G. Calvin Mackenzie. Baltimore, MD: Johns Hopkins University Press, 1987.

Kiel, L. J., and R. B. McKenzie. "The Impact of Tenure on the Flow of Federal Benefits to SMSA's." Public Choice, 41(2), 1983, 285-93.

Levitt, S. D., and J. M. Poterba. "Congressional Distributive Politics and State Economic Performance." Public Choice, 99(1-2), 1999, 185-216.

Light, P. C. Thickening Govemment. Washington, DC Brookings Institution, 1995.

Maddala, G. S. "Limited Dependent Variable Models Using Panel Data." Journal of Human Resources, 22(3), 1987, 307-38
Morgan, D. R., and J. T. LaPlant. "Federal Spending across States: An Analysis of Recent Trends." Social Science Quarterly, 77(2), 1996, 314-28.

Niskanen, W. A. Bureaucracy and Representative Government. Chicago, IL: Aldine and Atherton, 1971.

Plott. C. R. "Some Organizational Influences on Urban Renewal Decisions." American Economic Review, $58(2), 1968,306-21$.

Rich. M. J. "Distributive Polities and the Allocation of Federal Grants." American Political Science Review, 83(1), 1989, 193-213.

. Federal Policymaking and the Poor. Princeton, NJ: Princeton University Press, 1993.

Rundquist, B. S. Political Benefits. Lexington, MA: Lexington Books, 1980.

Rundquist, B. S., and J. A. Ferejohn. "Observations on a Distributive Theory of Policy Making: Two American Expenditure Programs Compared," in Comparative Public Policy: Issues, Theories and Methods, edited by $\mathrm{C}$. Liske, W. Loehr, and J. McCamant. New York: Wiley, 1975.

Sorauf, F. J. Inside Campaign Finance. New Haven, CT: Yale University Press, 1992.

Stein. R. M. "The Allocation of Federal Aid Monies: The Synthesis of Demand-Side and Supply-Side Explanations." American Political Science Review, 75(2), 1981, 334-43.

Stein, R. M., and K. N. Bickers, "Congressional Elections and the Pork Barrel." Journal of Politics, $56(1), 1994,377-400$.

Svorny, S. "Congressional Allocation of Federal Funds: The Job Training Partnership Act of 1982." Public Choice, 87(3-4), 1996, 229-42.

Wright, G. "The Political Economy of New Deal Spending: An Econometric Analysis." Review of Economics and Statistics, 56(1), 1974, 30-38. 